\title{
УПОТРЕБА ВЕЛИКОГ СЛОВА У ПИСМЕНИМ ЗАДАЦИМА УЧЕНИКА СРЕДЫИХ ШКОЛА ${ }^{1}$
}

\begin{abstract}
АПСТРАКТ
У раду доносимо ексцерпт из ширег истраживања поштовања ортографске норме у писменим задацима ученика средњих школа. Разматрамо употребу великог слова у 3.135 писмених задатака из шест школа различитих образовних профила и територијалне припадности. Резултати истраживања показали су да наши средњошколци у просеку праве 0,3 грешке у употреби великог слова у једном писменом задатку. Ученици најчешће греше на тај начин што мајускуле употребљавају тамо где не треба. Најслабија постигнућа у овој правописној области имају ученици првих и других разреда. Грешке у употреби великог слова најређе се јављају у најуспешнијим писменим задацима, а највећа заступљеност грешака испитиваног типа забележена је у комплекснијим и сложенијим радовима ученика специјализоване гимназије. Грешке у употреби великога слова су последица утицаја страних језика на српски, навика које су ученици стекли у електронској комуникацији, занемаривања наставе правописа већ у почетним разредима средње школе, изостанка повезаности наставе правописа и књижевности, али и недовољне оспособљености ученика да правописна правила примењују на разноврсним примерима када пишу своје писмене задатке. Сматрамо да у наставној пракси треба уложити додатни напор да би се функционална писменост ученика средњих школа унапредила.
\end{abstract}

1 Рад представља уобличен ексцерпт из докторске дисертације И. Ђорђев „Ортографска норма у писменим задацима ученика средњих школа као путоказ модерне наставе правописа", која је одбрањена на Филолошком факултету у Београду 2015. године пред комисијом у следећем саставу: проф. др Д. Вељковић Станковић, проф. др В. Брборић, проф. др Љ. Петровачки. 
Кључне речи: наставна пракса, писмени задаци, правопис, правописне грешке, средња школа, српски језик, употреба великога слова.

\title{
THE USAGE OF CAPITAL LETTERS IN WRITTEN PAPERS OF HIGH SCHOOL STUDENTS
}

\begin{abstract}
In this paper we present an extract from a larger research on high school student's adherence to the orthography norms in their written papers. The usage of capital letters will be analysed in 3.135 written papers from six schools, which differ both in profile and territorially. Research results show that high school students make in average 0.3 mistakes in the usage of capital letters in one written paper. The most common mistake is the use of capital letters where they must not be used. The weakest achievements in the field of orthography are among the students of the first and second year. Mistakes in the usage of capital letters are most common in the most successful written papers, and the highest density of mistakes in the usage of capital letter was in the papers of students from the specialized grammar schools. Mistakes in the usage of capital letters are the consequence of the influence of foreign languages on Serbian, the habit which they have gained during electronic communication, the neglection of orthography classes from the first years of high school, the lack of a connection between orthography and literature classes, but also the students' lack of ability to apply the orthography rules in the varied examples in their written papers. We believe that an extra effort should be made in teaching practice in order to improve functional literacy of high school students.
\end{abstract}

Key words: teaching practice, written papers, orthography, orthography mistakes, high school, Serbian language, the usage of capital letters.

\section{1. УВОД}

До краја првог циклуса образовања ученике треба оспособити да функционално примењују велико слово на почетку реченице, у писању личних имена, презимена и надимака, у именима животиња, код вишечланих географских имена, у писању адреса, у писању имена народа, празника, 
наслова књига, часописа и новина, у писању назива улица, имена држава, покрајина, насеља и њихових становника, у писању присвојних придева изведених од властитих имена (-ов/-ев, -ин), као и да употребљавају велико слово у управном говору. Дакле, до краја четвртог разреда ученици би требало да усвоје сва основна правописна правила употребе великог слова. ${ }^{2}$

У старијим разредима основне школе стечено знање се проверава, понавља и увежбава, проширујући се новим садржајима. Тако се у петом разреду обрађује писање назива разних организација и њихових тела (органа), те писање заменица у обраћању: Ви, Ваш; у шестом - писање имена васионских тела (једночланих и вишечланих). На крају основне школе, правописно градиво о употреби великог слова се систематизује. Након тога се, према програму за средње школе, правописно градиво о употреби великог слова понавља и проширује у првом разреду. ${ }^{3}$

Један од параметара којима се процењује поштовање ортографске норме у наставној пракси, а тиме и употребе великог слова као једне од основних правописних области, јесте правописна исправност ученичких писмених задатака. Према месту израде и утицају наставника на профилисање писменог рада, разликујемо: школске писмене задатке (међу њима и предмет интересовања овога рада - званичне писмене задатке), домаће писмене задатке и писмене вежбе.

„Школски писмени задаци су репрезентативни састави којима у одређеним периодима у току школске године хоћемо да видимо какве ефекте даје укупна настава културе изражавања, а посебно настава писме-

2 Наставни планови и програми за сваки разред основне школе доступни су и на сајту Завода за унапређивање образовања и васпитања: www.zuov.gov.rs (приступљено: 30. 3. 2016. године). Програми, законски и подзаконски акти (измене и допуне наставних програма) доступни су на сајту Министарства просвете Републике Србије (www.mp.gov.rs/propisi, приступљено: 30. 3. 2016. године).

3 В. Правилник о наставном плану и програму за гимназију у „Службеном гласнику СРС - Просветни гласник”, број 5/90 и у „Просветном гласнику”, бр. 3/91, 3/92, 17/93, 2/94, 2/95, 8/95, 23/97, 2/02, 5/03, 10/03, 11/04, 18/04, 24/04, 3/05, 11/05, 2/06, 6/06, 12/06, 17/06, 1/08, 8/08, $1 / 09,3 / 09,10 / 09$ и $5 / 2010$.

Правилник о плану и програму образовања и васпитања за заједничке предмете у стручним и уметничким школама у „Службеном гласнику СРС - Просветни гласник”, број 6/90 и „Просветном гласнику”, бр. 4/91, 7/93, 17/93, 1/94, 2/94, 2/95, 3/95, 8/95, 5/96, 2/2002, 5/2003, 10/2003, 24/2004, 3/2005, 6/2005, 11/2005, 6/2006, 12/2006, 8/2008, 1/2009, 3/2009, 10/2009, $5 / 2010$ и $8 / 2010$ - испр.).

Правилник о изменама правилника о плану и програму образовања и васпитања за заједничке предмете у стручним и уметничким школама (број: 110-00-00070/2012-03, од 18. марта 2013. године). 
ности” (П. И., Илић ${ }^{2} 1998:$ 616). Они имају - за разлику од других ученичких састава који су већином у служби систематичне обуке - „претежно контролну функцију” (Николић 52009: 716) и њима се уоквирују обимни радни циклуси.

П. Илић у делу Српски језик и књижевност у наставној теорији и пракси истиче да, „школски писмени задаци имају вредност и посебно значајног педагошког документа о ученику" (Илић ${ }^{2} 1998:$ 616). У Методици креативне наставе српског језика и кюижевности писмени задаци сматрају се „круном систематског рада на развијању писмене културе” (Маринковић 22000: 128).

Писмене задатке можемо сматрати веродостојним трагом кориговања и иновирања праксе; сваки писмени задатак представља и аутопортрет ученика који га пише и наставника који га на путу писмености води. Коначно, у писменим задацима уочава се какво је функционално знање ученика када је реч, између осталог, и о широкој и разнородној области каква је употреба великог слова, која нас у овом раду интересује.

\section{2. УПОТРЕБА ВЕЛИКОГ СЛОВА У ПИСМЕНИМ ЗАДАЦИМА УЧЕНИКА СРЕДЬИХ ШКОЛА}

\section{1. Методолошки оквир истраживања}

У овом раду доносимо ексцерпт из ширег истраживања поштовања ортографске норме у писменим задацима ученика средњих школа (в. Ђорђев 2015). Предмет дела истраживања који дискутујемо у овом раду јесте употреба великог слова у писменим задацима ученика средњих школа, а и̧иљ да се сагледа правописна исправност ових задатака ради унапређивања писменог изражавања ученика и наставе правописа у средњим школама.

Истраживањем се жели доћи до одговора на следеће питање: Каква је правописна исправност писмених задатака средњошколаца када је реч о употреби великога слова?

Задацчи истраживања су:

1. анализа ортографских карактеристика школских писмених задатака

ученика средњег образовања са аспекта употребе великога слова;

2. утврђивање просечне заступљености и укупног броја правописних грешака у употреби великога слова у писменим задацима средњошколаца с обзиром на узраст ученика;

3. утврђивање просечне заступљености и укупног броја правописних 
грешака у употреби великога слова у писменим задацима ученика средњих школа с обзиром на школе које ученици похађају;

4. одређивање просечне заступљености и укупног броја правописних грешака у правописној области Велико слово у писменим задацима средњошколаца сачињен према успеху ученика. ${ }^{4}$

Након одређивања циљева рада и увида у обиман корпус, поставили смо четири основне хипотезе истраживања.

(X1) Писмени задаци средњошколаца засићени су правописним грешкама у употреби великог слова.

(X2) У употреби великог слова најслабија постигнућа имају ученици на почетку средње школе.

(X3) Грешке у употреби великог слова најзаступљеније су у писменим задацима ученика трогодишњих стручних школа.

(X4) Грешке у употреби великог слова најређе се јављају у најуспешнијим писменим задацима (писменим задацима оцењеним одличним и врло добрим оценама).

Истраживани корпус је - зарад тачности и валидности резултата - обиман, а чини га 3.135 школских писмених задатака ученика средњих школа. Задаци су ексцерпирани из 1.000 ученичких вежбанки за писмене задатке предмета Српски језик и књижевност школске 2010/2011. године. За средњошколски ниво образовања определили смо се из више разлога: a) у средњој школи продубљује се и проширује правописно градиво које се усваја у основној школи, те би средњошколци морали да добро познају ортографску норму и примењују је у писменим задацима; б) ученици средњих школа, с обзиром на узраст, поседују већ развијен језички израз; в) завршетак средње школе је за неке ученике и крај формалног образовања и организованог рада на формирању писаног и језичког израза; г) ученици који продужавају школовање требало би да су оспособљени да прихвате и испуне захтеве високог образовања.

У овом истраживању (експлоративног карактера) коришћене су дескриптивна и аналитичка метода. У истраживању је коришћена и метода системског (неексперименталног) посматрања. Поред експиријског метода, квантитет се настојао претворити у квалитет да би се нашла веза ових података са теоријским оквиром. Стога је синтезом података у истраживању у

4 Ови резултати указали би на то које правописне теме треба шире обрадити на часовима редове наставе, а којим темама треба детаљније приступити на часовима допунске и додатне наставе матерњег језика у средњој школи. 
извесном смислу коришћен систематски приступ. Основно опредељење за овакав приступ нашло се у комплексности истраживане области.

Узорак је намерни - приликом избора школа водили смо рачуна о њиховој територијалној припадности и образовном профилу, тј. подручју рада и смеру школе који ученици похађају. Анализирани су радови ученика из Београда, Новог Сада, Вршца и Беле Цркве. ${ }^{5}$ Испитивањем су обухваћена одељења гимназија општег типа и гимназија са два смера (друштвенојезичким и природно-математичким), одељења специјализоване гимназије, као и стручних школа различитих образовних профила (за образовање фармацеута, физиотерапеута, техничара, економиста и саобраћајаца; в. Табелу бр. 1). Будући да су писмени задаци појединих ученика посматрани искључиво у оквиру њихове скупине (ученици једне школе чине један скуп), сагледан је и узорак скупине.

Табела бр. 1. Укупан број писмених задатака из сваке школе која је учествовала у истраживању

\begin{tabular}{|l|c|}
\hline \multicolumn{1}{|c|}{ Школа } & $\begin{array}{c}\text { Укупан број писмених } \\
\text { задатака }\end{array}$ \\
\hline Гимназија „Борислав Петров Браца”, Вршац & 752 \\
\hline Гимназија „Исидора Секулић”, Нови Сад & 227 \\
\hline Филолошка гимназија, Београд & 430 \\
\hline Школски центар „Никола Тесла”, Вршац & 794 \\
\hline Фармацеутско-физиотерапеутска школа, Београд & 541 \\
\hline Техничка школа „Сава Мунћан”, Бела Црква & 391 \\
\hline Укупно: 6 школа & 3.135 писмених задатака \\
\hline
\end{tabular}

\section{2. Припрема и ток истраживања}

Истраживању је претходила озбиљна и обимна припрема. Обављено је више неформалних разговора са наставницима школа које су укључене у истраживање. Одлучено је да се вежбанке прикупљају на крају школске 2010/2011. године да би се добио увид у што више писмених задатака ученика, и да се не би реметио наставни процес.

5 Одабране су школе из различитих градова због релевантности резултата истраживања, као и да би се добио обимнији и разноврснији корпус за истраживање. 
Задаци су прикупљени брзо захваљујући спремности наставника да сарађују. Иако су се наставници трудили да пошаљу вежбанке ученика свих разреда, прикупљено је 1.327 писмених задатака првака ${ }^{6}, 667$ писмених задатака ученика другог разреда, 687 писмених задатака ученика трећег разреда и 454 задатка које су радили ученици на крају средњег образовања. Број писмених задатака у једној вежбанци кретао се 1-4, у зависности од типа школе, али и од присутности ученика на часовима посвећеним изради писмених задатака. ${ }^{7}$

За систематизацију правописних тема узета је подела правописне материје у Правопису српскога језика (приручнику за школе) Милорада Дешића ( $\left.{ }^{2} 1995\right)$, која се учинила најподеснијом за планирано истраживање; унете су и поједине измене, углавном у додавању ужих правописних тема, тамо где се на пробном узорку од око 167 вежбанки показала потреба.

Будући да су сви писмени задаци рађени током школске 2010/2011. године, одлучено је да поштовање правописне норме у њима буде посматрано према норми прописаној у Правопису српскога језика Матице српске из 1993. године (П 1993), са посебним напоменама тамо где се у Правопису српскога језика Матице српске из 2010. године ${ }^{8}$ (П 2010) забележене уже правописне ставке другачије нормирају. ${ }^{9}$

Као најоперативнија за систематизацију и праћење правописних грешака показала се израда табела у Ексел програму (енгл. Microsoft Office Excel 2007). Овај програм омогућава да се унесени резултати (правописне грешке из писмених задатака) класификују по школама, узрасту и успеху ученика. Ексел омогућава да се сумирају сви резултати истраживања. Извршено је и извесно прилагођавање софтвера циљевима испитивања.

6 У обзир је узет дупло већи број писмених задатака првака, будући да се у њима пресликава знање ученика и из основне школе, те може послужити као основа за даља истраживања. Исто тако, када је прикупљан корпус, није се знало колико ће се вежбанки тачно сакупити, што оправдава и неједнак број вежбанки преузет из различитих школа.

7 Када смо прегледали сакупљени корпус, уочили смо да се у 22 вежбанке налази само по један писмени задатак, а да је 7 вежбанки само са попуњеном насловницом.

8 Измењено и допуњено издање Правописа српскога језика изашло је крајем 2010. године када је школска 2010/2011. година већ била у току. Употреба овог измењеног и допуњеног издања практично је била на снази од почетка школске 2011/2012. године. (Напомињемо да је 2015. године изашло измењено и допуњено 3. екавско издање, $\left.\Pi^{3} 2015\right)$.

9 О изменама и допунама Правописа српскога језика Матице српске (Речник уз Правопис) в. Ђорђев (2011: 120-136); о изменама и допунама Правописа српскога језика Матице српске у додатној настави српског језика у средњој школи в. Ђорђев (2012: 91-117). 


\section{3. Ограничења истраживања}

Овим истраживањем може се добити потпуна и валидна слика о поштовању ортографске норме када је реч о употреби великог слова у писменим задацима ученика школа које су учествовале у истраживању, и то за школску 2010/2011. годину, када су писани писмени задаци који су уврштени у корпус. Међутим, на другом корпусу (нпр. писменим задацима ексцерпираним из других крајева наше земље, у другом временском периоду) могући су и нешто другачији резултати. Ипак, с обзиром на обим корпуса, сматрамо да ово истраживање може бити добар путоказ ка модерној настави правописа и основа за даља (упоредна и сл.) истраживања са ортографског и методичког становишта, која би, изведена у одређеним временским размацима, показала у ком правцу се креће настава правописа у нашој земљи. Коначно, свесни смо да је за неке правописне проблеме тешко наћи материјал у писменим задацима, што је условљено првенствено типом писаног текста који смо истраживали.

\section{4. Резултати и дискусија}

2.4.1. Укупан број, прочентуална заступљеност и типови грешака у употреби великог слова у писменим задацима средњошколаиа

У вежбанкама које смо прегледали уочено је 777 грешака у употреби великог слова (в. Табелу бр. 2). Наши средњошколци у просеку праве 0,3 грешке у употреби великог слова у једном писменом задатку.

У Табели бр. 2. приказана је и фреквентност ових грешака у:

а) личним именима и именима божанстава;

б) именима животиња;

в) именима ликова из уметничких дела;

г) именима народа, држава и административних јединица;

д) именима насеља и њихових становника;

ђ) географским и астрономским називима;

е) називима организација, манифестација и институција;

ж) називима празника, историјских догађаја и покрета;

3) насловима чланака, књига и уметничких дела.

Исто тако, посматрана је заступљеност грешака када је реч о употреби великог слова на почетку реченица и у речима из поштовања. У овим случајевима велико слово је у писменим задацима наших средњошколаца изостало. Међутим, уочили смо, како показује Табела бр. 2, и примере 
у којима су ученици погрешно употребили велико слово. Запазили смо, такође, и два примера у којима су ученици погрешно употребили велико слово приликом адресирања (ове грешке уврстили смо у категорију Разно).

Табела бр. 2. Укупан број и процентуална заступљеност грешака у употреби великог слова у писменим задацима средњошколаца

\begin{tabular}{|l|c|c|}
\hline Велико слово & $\begin{array}{c}\text { Укупан број } \\
\text { грешака }\end{array}$ & $\begin{array}{c}\text { Процентуална } \\
\text { заступљеност }\end{array}$ \\
\hline лична имена и имена божанстава & 59 & $7,60 \%$ \\
\hline имена животиња & 2 & $0,26 \%$ \\
\hline имена ликова из уметничких дела & 127 & $16,34 \%$ \\
\hline имена народа, држава и админ. јединица & 83 & $10,68 \%$ \\
\hline имена насеља и њихових становника & 37 & $4,76 \%$ \\
\hline географски и астрономски називи & 44 & $5,66 \%$ \\
\hline називи организација, манифестација и институција & 24 & $3,09 \%$ \\
\hline називи празника, истор. догађаја & 35 & $4,50 \%$ \\
\hline наслови чланака, књига, ум. дела & 91 & $11,71 \%$ \\
\hline прва реч у реченици, огласу, обрасцу и сл. & 119 & $15,32 \%$ \\
\hline речи из поштовања & 4 & $0,51 \%$ \\
\hline велико слово где не треба & 150 & $19,31 \%$ \\
\hline разно & 2 & $0,26 \%$ \\
\hline Укупно & 777 & $100 \%$ \\
\hline
\end{tabular}

Средњошколци у својим писменим задацима највише греше јер мајускуле употребљавају тамо где не треба (укупно је 150 грешака, УПЗВС $\left.{ }^{10}=19,31 \%\right)$, нпр. ${ }^{11}$ :

Хектор је Ахилеју убио Интимног пријатеља Патрокла; Ми живимо у таквом Свету, Свету пуном недостатака; Живео Свет коике; Када смо крочили у Средњу школу, желели смо да се часови што пре заврше како бисмо побегли од обавеза; Дува Кошава; Почео је 1. Сеп-

10 УПЗВС - укупна процентуална заступљеност грешака према свим грешкама забележеним у вези са употребом великог слова.

11 Ради боље прегледности, примере са грешкама доносимо у посебним пасусима (увучено, без прореда). 
тембар; Пишем и читам Чешки језик; Садржи Словенску антитезу за опис пејзажа.

Неправилну употребу великог слова забележили смо и у примерима:

y Јеврејској религији; према Библијским и реалним грешнищима; сви Косовски јуначи; велика Турска снага; једне Вишеградске вечери; у Европском граду; прошли Божићни дани; прошлог Децембра; на Јесен; Српски језик и Кюижевност [в. илустрацију бр. 1]; Свеска за писмене задатке из Српског Језика; моја Мама; мој Тата; мој Ујка; последњих Месец дана; Писии Хуманизма и ренесансе.

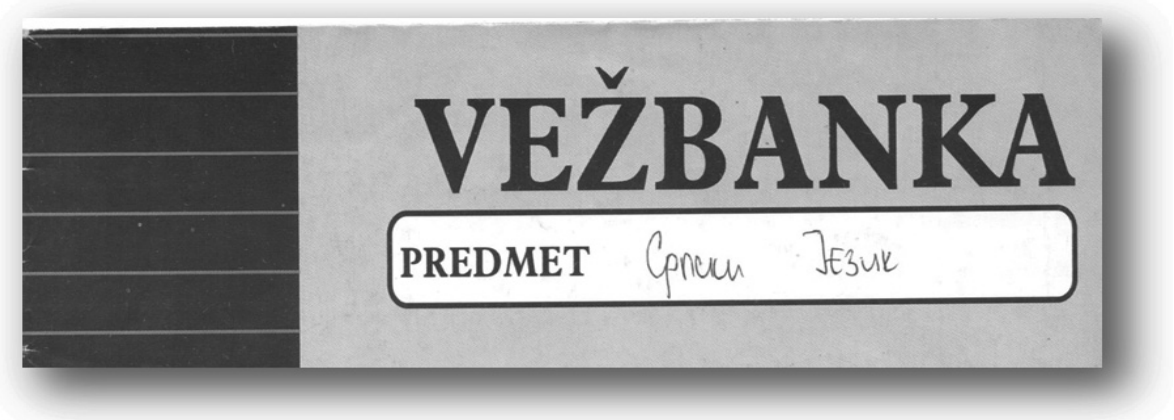

Илустрација бр. 1. Насловна страна вежбанке на којој се уочава, поред осталог, и погрешно употребљена мајускула у називу школског предмета (без исправке наставника)

Ученици неправилно употребљавају велико слово за називе месеци у години, у конструкцијама са именицом свет и у присвојним придевима изведеним суфиксом -ски.

Ове грешке су вероватно последица утицаја страних језика на српски. Називи календарских месеци у енглеском (и немачком) језику пишу се великим почетним словом (уп. Почео је 1. Септембар ${ }^{12}$ : енгл. The $1^{\text {st }}$ September), а великим словом пишу се, према енглеској норми, и имена језика (уп. Пишем и читам Чешки језик : енгл. The Czech language.). Показало се да ученици не разликују увек присвојне придеве од властитих имена (уп. Турска: турски) и недовољено познају правила о писању придева изведених од властитих имена у српском језику (уп. Косово : косовски, Божић : божићни).

12 Примере грешака у основном тексту дајемо курзивним писмом. 
Велико слово се неоправдано нашло и називима уметничких и стилских праваца и називима стилских фигура: Писии Хуманизма и ренесансе; Садржи Словенску антитезу за опис пејзажа. Белешке наставног градива у школским свескама нису правописно коректно записане, ученици ретко користе секундарну литературу када се припремају за писмене задатке; више размишљају о садржају написанога (уп. Николић ${ }^{2} 1992: 583$ ). Очито је да не користе ни уџбенике (читанке).

Велико слово средњошколци користе и када њиме желе да нешто истакну - такви су примери типа: мој Тата ${ }^{13}$, Српски језик и Књижевност, Ми живимо у таквом Свету, Свету пуном недостатака. У првом примеру ученик је истакао важност очеве личности у свом животу, на когнитивном плану дошло је до повезивања квантитета и значаја (уп. ВЕЛИКО ЈЕ ВРЕДНО, ЗНАЧАЈНО, Klikovac 2004: 111). У другом примеру ученик је показао да Српски језик и књижевност не осећа као јединствени наставни предмет(!), у трећем великим словом употребом мајускуле нагласио је осећања према свету који га окружује.

Ученици су изоставили велико слово у именима ликова из уметничких дела (укупно је 127 грешака овога типа, УПЗВС = 16,34\%), нпр.:

Ослободио је хасана; Двогубост лика софке; ромеово писмо; син Ђорђо; карађоз.

Тиресија је утицао на креонтову промену одлуке о кажњавању Антигоне; Слуга ла Флеш разговара са Харпагоном.

Посебан проблем ученици имају када треба да употребе велико слово у двосложним и тросложним именима историјских и других личности:

Браћа ћирило и Методије су задужили словенски народ; Вергилије је чувао Дантеа као и Стефан неману; Урош нејаки; Стефан немања; Исидора секулић; Антон Павлович чехов.

Грешке овога типа могу се посматрати и као нехотичне грешке, које су најчешће последица немарности (нпр. Исидора секулић), али и изостанка аутокорекције писмених задатака.

Ученици нису употребили велико слово на почетку реченице у 119 примера (УПЗВС $=15,32 \%)$, иако ово правописно градиво усвајају већ

13 У другом писменом задатку наишли смо на пример у којем су употребљена сва велика слова за издвајање овог дела текста: Дошао је мој ТАТА. 
на почетку основношколског образовања. ${ }^{14}$ Грешке овога типа илуструју следећи примери:

Живот је највећи и најлепши дар. понекад може бити суров.

Један друг је рекао да можемо отићи за викенд. сложили смо се.

Волим да се вратим у детиюство. могао бих да се играм са играчкама и ништа да не радим и немам обавеза.

Много је волим. не знам ита бих без юе.

И даље ћу их виђати, на одморима и ван школе. једина разлика је та што неће бити ту да ми скрате понекад предугачке и досадне часове. Неколико дана раније у мојој кући се разговарало о братовом понашағу. мама и тата су га грдили.

Кьигу сам прочитала два пута и сваки пут плакала. то је исповест девојчице која је уместо ведрог и безбрижног детињства, пролазила кроз тежак живот наркомана.

Исте грешке забележене су у управном говору и дијалогу:

Газда је рекао: „зваћемо вас, стрпите се!”

Одрасли су одговорили: ,,нема везе, још је мали!”

Анализом примера ексцерпираних из писмених задатака средњошколаца уочили смо да су реченице које ученици започињу малим словима у тешњој смисаоној вези са претходним реченицама (са реченицама иза којих се налазе) или доносе додатне информације (уп. Кюигу сам прочитала два пута и сваки пут плакала. то је исповест девојчиџе која је уместо ведрог и безбрижног детињства, пролазила кроз тежак живот наркомана.). Изгледа да ученици имају проблема да одреде крај реченице, тј. да правилно одреде реченицу као мисаону целину, па је прекидају тачком (не познајући довољно могућности других интерпункцијских знакова) тамо где не треба, а остављају мало слово на почетку наредне. Не може се тврдити да је реч само о непознавању правилне употребе великог слова (уочава се да

14 Према Наставном програму образовања и васпитања за први и други разред основног образовања и васпитања, стр. 5 (програм је доступан на сајту ЗУОВ-a, www.zuov.gov.rs) и Правилнику о наставном плану и програму основног образовања и васпитања (в. „Службени гласник СРС - Просветни гласник”, бр. 4/90 и „Службени гласник РС - Просветни гласник”, бр. $1 / 91$, бр. $2 / 92,13 / 93,1 / 94,5 / 95$ и $6 / 96$. године) у првом разреду основне школе треба обрадити следеће:

Употреба великог слова на почетку реченице, у писању личних имена и презимена, имена насеља. Правилно потписивање (име па презиме). Употреба тачке на крају реченице. Уочавање места и функиије упитника и узвичника у реченици. 
ученици прву реченицу у низу редовно започињу великим словом) и тачке у питању је и недостатак лексичке компетенције код ученика ${ }^{15}$ и недовољно развијена метајезичка свест ${ }^{16}$, како је показало раније истраживање језичких особина ученика у школама средњег образовања (исп. Петровић 1999). ${ }^{17}$ Овакви резултати откривају системске пропусте и у обради и у утврђивању градива, а такође и превелику попустљивост у оцењивању.

У употреби великог слова у насловима књига, чланака и уметничких дела ученици су погрешили 91 пут (УПЗВС = 11,71\%), нпр.:

Посматрам Ботичелијеву слику „,рађање пролећа”; у делу проклета авлија / Проклета Авлија; куран; У хасанагиници је дочарана нераскидива веза између мајке и деце; На почетку епа о гилгамешу; у Раним Јадима; У књизи о Јову; Потреба за сродном душом се испољава и у старом завету; Домановићево Мртво Море; Башта Сљезове боје; Новела од стания; у новели Старач и Море; у делу Слово Љубве Деспота Стефана Лазаревића; У епу о Гилгамешу као врховно божанство јавља се бог Ану; на дрини ћуприја / у средишту осмог поглавља Андрићевог романа на Дрини Ћуприја. / На Дрини Ћуприја; кроника Паланачког гробља; Јуначи сеоба различити су по много чему; Вук издаје писменищу српског језика; у Горском Вијениу / Горски Вијенац.

Већина грешака у употреби великог слова у насловима књига, чланака, уметничких дела јавља се у вишечланим називима. Тако, на пример, ученици у трочланим именовањима велико слово употребљавају без правила, показујући притом да не разликују властито име од опште именице, као и да не знају како се пишу опште именице у оквиру вишечланих назива. Наслов романа нашег нобеловца ученици су написали на три начина: све малим словима (на дрини ћуприја), све великим словима (На Дрини hуnрија) и тако што су велико слово употребили у општој именици ћуприја (На дрини Ћуnрија), а изоставили га тамо где треба да стоји - приликом именовања реке. Исто тако, велико слово је изостало у називу сликарског

15 Непознавање правописних правила јавља се у ученичким писменим задацима напоредо са неправилном употребом речи и израза у одређеном текстовном типу (исп. Петровић 1999: 140).

16 Ученици који нису у могућности да оформе реченицу имају ниске оцене и на тестовима граматичке компетенције (исп. Петровић 1999: 43), што је један од показатеља да непознавање правописних правила подразумева и неразвијену метајезичку свест.

17 Томе у прилог иду и примери са изостављањем великог слова у конструкцијама са управним говором у којима се цитирани део текста означава погрешно малим словом, јер ученици не увиђају да тај текст припада другом говорнику. 
дела - Посматрам Ботичелијеву слику „,рађање пролећа”. Иако је ученик показао да зна да је реч о називу уметничког дела стављајући га под наводнике ${ }^{18}$, није правилно употребио велико слово. Писање сваке речи великим почетним словом (као у примеру: На Дрини Ћуприја) погрешно је и долази под утицајем различитих натписа (у које спадају имена фирми, плакати, постери, рекламе, билборди, огласи) и енглеског језика (у насловима на енглеском језику великим почетним словом пишу се све речи сем предлога, везника и чланова).

Ученици су у својим писменим задацима направили 83 грешке у употреби великог слова приликом писања имена народа, држава и административних јединица (УПЗВС $=10,68 \%$ ). Тако су, на пример, употребили мало слово у примерима:

турчин, турци, против турака; немица Ана Марија Краус, бечлијка; цчиганка, циганин бањски, млада цчиганка, роми, румун, мађар; Библија је верско дело јевреја - једнобожачког народа; аустроугарска, ауcmроугари.

Велико слово се у задацима средњошколаца неправилно употребљава у примерима са присвојним придевом изведеним од именице Србија:

огорченим Српским народом; у историји Српског народа; борећи се за Српску државу; сеоба Српског народа.

Исто тако, великим словом започињу се присвојни придеви (на -cкu, -чки, -ики) изведени од имена неких суседних и несуседних народа:

Прошли смо Македонску и Грчку границу; Има Кинеских, Индијских, Италијанских ресторана; Задивили су ме Менелај и остали Грчки и тројански јунаци; велики Грчки јунаџฺи.

Наведени примери су последица утицаја енглеске норме - придеви изведени од имена народа у енглеском језику пишу се великим почетним словом (исп. Vlajković 2010: 185).

Ученици најмање греше када мајускуле треба да употребе у личним именима и именима божанстава (УПЗВС $=7,60 \%)$, затим у географским и астрономским називима (5,66\%), у именима насеља и њихових становника (4,76\%), у називима празника, историјских догађаја и покрета (4,50\%), те

18 Употреба наводника у овом случају није обавезна будући да се испред назива дела стоји одређење: слику, в. $\Pi^{3} 2015$ : 135, т. 169 нап. 
када пишу имена институција и њихових делова, организација и удружења, манифестација и сл. (свега 3,09\%). Мала заступљеност грешака последица је тога што ученици врло мало и користе нпр. имена божанстава, географске називе, имена институција и сл. у својим писменим задацима.

Изабрани примери из писмених задатака:

(a) грешке у писању личних имена и имена божанстава:

снешко белић, девојка катиц̧а, вики, мики, Никола тесла, ђорђе, страхиња, божић бата, јефимија описује све лепоте које је господ створио;

(б) астрономски и географски називи:

Устао сам, Сунце је сијало, птице су цьвркутале; Када волимо, небо је плавље, Суние лепше сија; Лежао сам на ситном песку прегрејаном од Сунчевих зрака; Појио га је вином и изводио на Сунцен; Немо сам стајала изнад дубоке, хладне реке, изучавајући одраз Месеца; Волим Залазак Сунияа;

Фрушка Гора, речица месић, вршачки брег, косово, из малене бањске, повратак из сахаре, Екс понто, Стара Планина; Отишао сам до дунава;

(в) имена насеља и юихових становника:

аргејчи, дубровчани, београђанка; Бела чрква, вриач, Врачев гај, Сремски карловци, америка, европа, крушевач, ђавоља варош, данска, мађарска [али: Македонија, Немачка, Холандија, Швајцарска, Румунија], јаношик;

(г) називи празника и историјских догађаја:

Нова Година / нова година; други светски рат / Други Светски рат, први српски устанак, сеоба срба, након косовског боја; бадюи дан, Бадње Вече;

(д) називи организација, манифестација и институција:

По завршетку Основне Школе; Факултет Организационих Наука; Школски Центар „Никола Тесла”; Желео бих да упишем филозофски 
факултет у Новом Саду; Манастир троноша; Уједињене Нације; Матииа Српска; парада поноса; дани бербе грожђа.

Проценат заступљености грешака које се тичу употребе мајускула у речима из поштовања мањи је од $1 \%$, будући да се ове речи врло ретко користе у писменим задацима. На случајном узорку од 100 вежбанки забележена је само једна реч из поштовања, што указује на то да их у целом истраживаном корпусу има око десет. Исто важи и за употребу великог слова у именима животиња и именима градских улица и тргова.

Не можемо констатовати, ако се у обзир узме број и процентуална заступљеност грешака, да је $X 1$ потврђена. Међутим, иако заступљене у малом проценту, све описане грешке последица су неувежбавања и недовољне примене правописног знања усвојеног током основношколског образовања. Исто тако, указују на мањкавост наставе правописа у првом разреду средње школе када стечено знање треба додатно увежбавати и проширити.

Велико слово је изостало у писменим задацима средњошколаца и под утицајем електронске комуникације и комуникације путем мобилних телефона, у којој се „најчешће прибегава употреби само малих слова” (Vlajković 2010: 186). Исто тако, чини се да ученици више пажње посвећују садржају (важно им је да напишу назив књижевних дела или правца), но томе колико је то што је написано правописно коректно. Посматране грешке указују нам да је у примени правописних захтева неизбежно повезивање лингвистичких и нелингвистичких знања.

2.4.2. Заступљеност и фреквентност грешака у употреби мајускула према узрасту ученика, иколи и оцени писмених задатака

Највише грешака у употреби великог слова пронашли смо у писменим задацима ученика првих и других разреда. Ученици првог разреда у просеку су начинили 0,27 грешака у једном писменом задатку (в. Табелу бр. 3 ), ученици другог разреда 0,30 . То указује на занемаривање наставе правописа у оном сегменту који се односи на трајност и применљивост знања већ на почетку средњег образовања. У првом разреду наставним програмом прописано је увежбавање употребе великог слова, те се очекује да ученици у другом разреду мање греше у правописној теми која је обрађена на часовима редовне (евентуално додатне и допунске) наставе у првом разреду. Како је истраживање показало, у наставној пракси изгледа да то није случај. Ученичко знање на почетку средње школе, када је реч о употреби великог слова, стагнира. Заступљеност грешака смањује се у трећем и четвртом 
разреду средње школе. У писменим задацима ученика трећег разреда има у просеку 0,20 грешака у једном писменом задатку, док у задацима ученика завршних разреда средњег образовања просечан број грешака у писменим задацима износи 0,17. Добијени резултати о заступљености и фреквентности грешака у употреби мајускула према узрасту ученика потврдили су $X 2$.

Табела бр. 3. Правописне грешке у употреби великог слова у односу на узраст ученика

\begin{tabular}{|l|c|c|c|}
\hline Узраст ученика & $\begin{array}{c}\text { Укупан број } \\
\text { грешака }\end{array}$ & $\begin{array}{c}\text { Просечан број } \\
\text { грешака у једном } \\
\text { писменом задатку }\end{array}$ & $\begin{array}{c}\text { Процентуална } \\
\text { заступљеност }\end{array}$ \\
\hline Први разред & 363 & 0,27 & $29,06 \%$ \\
\hline Други разред & 201 & 0,30 & $32,03 \%$ \\
\hline Трећи разред & 138 & 0,20 & $21,35 \%$ \\
\hline Четврти разред & 75 & 0,17 & $17,56 \%$ \\
\hline
\end{tabular}

У употреби великог слова најмање греше ученици Фармацеутско-физиотерапеутске школе у Београду, који су начинили у просеку 0,14 грешака у једном задатку (в. Табелу бр. 4). На ово је несумњиво утицала тематика писмених задатака. У специјализованој гимназији већина тема за писмене задатке захтева од ученика анализе књижевних дела, компарације више дела истог или различитих аутора, те су њихови писмени задаци сложенији и комплекснији, засићени примерима употребе великог слова. Насупрот томе, задаци ученика средње стручне школе су мањега обима и захтева са већом могућношћу да се (не)намерно избегне употреба великог слова, поготово када је реч о насловима књижевних дела, именима јунака или писаца. Полазна $X 3$ није, дакле, потврђена (у тумачењу ових резултата позивамо се и на ограничења истраживања). Заступљеност грешака у писменим задацима ученика осталих школа, приказана је у Табели бр. 4. 
Табела бр. 4. Правописне грешке у употреби великог слова према школама које ученици похађају

\begin{tabular}{|l|c|c|c|}
\hline Школа & $\begin{array}{c}\text { Укупан број } \\
\text { грешака }\end{array}$ & $\begin{array}{c}\text { Просечан број грешака } \\
\text { у једном писменом } \\
\text { задатку }\end{array}$ & $\begin{array}{c}\text { Процентуална } \\
\text { заступљеност }\end{array}$ \\
\hline ГВ & 189 & 0,25 & $17,78 \%$ \\
\hline ГНС & 33 & 0,15 & $10,28 \%$ \\
\hline ФГ & 154 & 0,36 & $25,34 \%$ \\
\hline ШЦВ & 240 & 0,30 & $21,38 \%$ \\
\hline ФФБ & 78 & 0,14 & $10,20 \%$ \\
\hline ТШБЦ & 83 & 0,21 & $15,02 \%$ \\
\hline
\end{tabular}

Легенда: ГВ - Гимназија „Борислав Петров Браца”, Вршац; ГНС Гимназија „Исидора Секулић”, Нови Сад; ФГ - Филолошка гимназија, Београд; ШЦВ - Школски центар „Никола Тесла”, Вршац; Фармацеутско-физиотерапеутска школа, Београд; ТШБЦ - Техничка школа „Сава Мунћан”, Бела Црква

Када је реч о прегледу ортографских грешака у употреби великога слова према успеху ученика, грешке су посматране према заступљености и фреквентности у вежбанкама, а не у писменим задацима, како је то до сада чињено. Евидентирана је средња оцена коју ученик има на писменим задацима у оквиру једне вежбанке. Како показује Табела бр. 5, грешке у употреби великог слова најређе се јављају у најуспешнијим писменим задацима (просечан број грешака износи 0,46 по једној вежбанци). Тиме је потврђена $X 4$.

Ових грешака има скоро дупло више у задацима ученика који добијају ниже оцене. Највиши просечан број грешака из испитиване области $(1,36)$ уочили смо у радовима ученика чија је средња оцена писмених задатака довољан (2). 
Табела бр. 5. Правописне грешке у употреби великог слова према успеху ученика

\begin{tabular}{|c|c|c|c|}
\hline $\begin{array}{c}\text { Просечна оцена } \\
\text { писмених задатака }\end{array}$ & $\begin{array}{c}\text { Укупан број } \\
\text { грешака }\end{array}$ & $\begin{array}{c}\text { Просечан број грешака } \\
\text { у једној вежбанци }\end{array}$ & $\begin{array}{c}\text { Процентуална } \\
\text { заступљеност }\end{array}$ \\
\hline 1 & 12 & 0,80 & $18,74 \%$ \\
\hline 2 & 140 & 1,36 & $31,84 \%$ \\
\hline 3 & 227 & 0,86 & $20,14 \%$ \\
\hline 4 & 304 & 0,79 & $18,54 \%$ \\
\hline 5 & 94 & 0,46 & $10,74 \%$ \\
\hline
\end{tabular}

\section{3. ЗАКЉУЧАК О УПОТРЕБИ ВЕЛИКОГ СЛОВА У ПИСМЕНИМ ЗАДАЦИМА УЧЕНИКА СРЕДЬИХ ШКОЛА}

Ученици су показали много боље знање на тестовима када се од њих директно захтевало да употребе велико слово (исп. Брборић 2004: $114,223)^{19}$ него када знање о употреби великог слова треба да примене у својим писменим задацима. Грешке које смо забележили последица су утицаја страних језика на српски, навика које су ученици стекли у електронској комуникацији, занемаривања наставе правописа већ у почетним разредима средње школе, изостанка повезаности наставе правописа и књижевности, али и недовољне оспособљености ученика да правописна правила примењују на разноврсним примерима када пишу своје писмене задатке. Ови резултати су поуздан показатељ потребе за додатним напором у наставној пракси да би се функционална писменост наших ученика унапредила.

У припреми за израду писмених задатака, у домаћим задацима, вежбањима требало би уврстити теме које захтевају да у писменим радовима ученика има више имена из уметничких дела, наслова књижевних дела, топонима, историјских догађаја и сл. Када се на часовима књижевности наиђе на вишесложна имена ликова из књижевних дела и писаца, као и на називе епоха, ученицима би требало показати како се ова имена правилно пишу.

19 Када се пажљивије погледа коначан број и проценат тачних одговора на тестовима и диктатима којима је испитивано правописно знање ученика, можемо рећи да су ученици средњих школа показали најбоље знање баш када је реч о употреби великог слова - ученици су дали 77,9\% тачних одговора на питања из ове правописне области (исп. Брборић 2004: 223). 
Вежбе треба диференцирати према узрасту ученика, али и према успеху који ученици остварују на писменим задацима. У осмишљавању вежби треба кренути и од пажљивог испитивања грешака.

Коначно, описане правописне грешке у употреби великога слова у писменим задацима ученика и утврђивање њихове учесталости добар су показатељ у ком правцу треба усмерити наставу, које теме треба темељније обрађивати и у настави и у методичкој литератури да би се знање ученика ефикасније унапредило.

\section{ЛИТЕРАТУРА}

Брборић, В. (2004). Правопис српског језика у наставној пракси. Београд: Чигоја штампа. [Brborić, V. (2004). Pravopis srpskog jezika u nastavnoj praksi. Beograd: Čigoja štampa.]

Дешић, М. (21995). Правопис српског језика: приручник за школе. Земун: Нијанса, Никшић: Унирекс, Београд: Пословни систем Грмеч - Привредни преглед. [Dešić, М. ( $\left.{ }^{2} 1995\right)$. Pravopis srpskog jezika: priručnik za škole. Zemun: Nijansa, Nikšić: Unireks, Beograd: Poslovni sistem Grmeč - Privredni pregled.]

Ђорђев, И. (2011). „Измене и допуне Правописа српског језика Матице српске (Речник уз Правопис)". Школски час српског језика и књижевности 28/ 5: 120-136. [Đorđev, I. (2011). „Izmene i dopune Pravopisa srpskog jezika Matice srpske (Rečnik uz Pravopis)". Školski čas srpskog jezika i književnosti 28/ 5: 120-136.]

Ђорђев, И. (2012). „Измене и допуне Правописа Матице српске у додатној настави српског језика у средњој школи”. Методички видици 3: 91-117. [Đorđev, I. (2012). „Izmene i dopune Pravopisa Matice srpske u dodatnoj nastavi srpskog jezika u srednjoj školi”. Metodički vidici 3: 91-117.]

Ђорђев, И. (2015). Ортографска норма у писменим задацима ученика средњих школа као путоказ модерне наставе правописа (необјављена докторска дисертација). Београд: Универзитет у Београду, Филолошки факултет. [Đorđev, I. (2015). Ortografska norma u pismenim zadacima učenika srednjih škola kao putokaz moderne nastave pravopisa (neobjavljena doktorska disertacija). Beograd: Univerzitet u Beogradu, Filološki fakultet.] 
Илић, П. (21998). Српски језик и књижевност у наставној теорији и пракси: методика наставе. Нови Сад: Змај. [Ilić, P. ('21998). Srpski jezik $i$ književnost u nastavnoj teoriji i praksi: metodika nastave. Novi Sad: Zmaj.]

Klikovac, D. (2004). Metafore u mišljenju i jeziku. Beograd: Čigoja štampa.

Маринковић, С. (2000). Методика креативне наставе српскога језика и къижевности. Београд: Креативни центар. [Marinković, S. (22000). Metodika kreativne nastave srpskoga jezika $i$ književnosti. Beograd: Kreativni centar.]

Николић, М. ${ }^{2} 1992$ [52009]. Методика наставе српскога језика и къижевности. Београд: Завод за уџбенике и наставна средства. [Nikolić, M. ${ }^{2} 1992$ [52009]. Metodika nastave srpskoga jezika $i$ književnosti. Beograd: Zavod za udžbenike i nastavna sredstva.]

Петровић, А. (1999). Језичке особине ученика у школама средњег образовања (необјављена докторска дисертација одбрањена марта 2000. год. на Филолошком факултету у Београду). Београд: Универзитет у Београду, Филолошки факултет. [Petrović, А. (1999). Jezičke osobine učenika u školama srednjeg obrazovanja (neobjavljena doktorska disertacija odbranjena marta 2000. god. na Filološkom fakultetu u Beogradu). Beograd: Univerzitet u Beogradu, Filološki fakultet.]

[П 1993]: Правопис српскога језика. І. Правила и њихови основи. ІІ. Речник уз правопис, приредили: Митар Пешикан, Јован Јерковић, Мато Пижурица. Нови Сад: Матица српска. [[Р 1993]: Pravopis srpskoga jezika. I. Pravila i njihovi osnovi. II. Rečnik uz pravopis, priredili: Mitar Pešikan, Jovan Jerković, Mato Pižurica. Novi Sad: Matica srpska.]

[П 2010, 32015]: Правопис српскога језика (измењено и допуњено екавско издање), приредили: Митар Пешикан, Мато Пижурица, Јован Јерковић; редакција измењеног и допуњеног издања: Мато Пижурица (главни редактор), Милорад Дешић, Бранислав Остојић, Живојин Станојчић. Нови Сад: Матица српска. [[Р 2010, 32015]: Pravopis srpskoga jezika (izmenjeno i dopunjeno ekavsko izdanje), priredili: Mitar Pešikan, Mato Pižurica, Jovan Jerković; redakcija izmenjenog i dopunjenog izdanja: Mato Pižurica (glavni redaktor), Milorad Dešić, Branislav Ostojić, Živojin Stanojčić. Novi Sad: Matica srpska.] 


\section{Наставни програми}

Правилник о наставном плану и програму основног образовања $и$ васпитања, у Службени гласник СРС - Просветни гласник, бр. 4/90 и Службени гласник РС - Просветни гласник, бр. 1/91, бр. 2/92, 13/93, 1/94, 5/95 и 6/96. год. [Pravilnik o nastavnom planu i programu osnovnog obrazovanja i vaspitanja, u Službeni glasnik SRS - Prosvetni glasnik, br. 4/90 i Službeni glasnik RS - Prosvetni glasnik, br. 1/91, br. 2/92, 13/93, 1/94, 5/95 i 6/96. god.]

Правилник о наставном плану и програму за гимназију у Службени гласник СРС - Просветни гласник, бр. 5/90 и у Просветни гласник, бр. 3/91, 3/92, 17/93, 2/94, 2/95, 8/95, 23/97, 2/02, 5/03, 10/03, 11/04, 18/04, 24/04, 3/05, 11/05, 2/06, 6/06, 12/06, 17/06, 1/08, 8/08, 1/09, 3/09, 10/09 и 5/2010. [Pravilnik o nastavnom planu i programu za gimnaziju u Službeni glasnik SRS - Prosvetni glasnik, br. 5/90 i u Prosvetni glasnik, br. 3/91, $3 / 92,17 / 93,2 / 94,2 / 95,8 / 95,23 / 97,2 / 02,5 / 03,10 / 03,11 / 04,18 / 04$, $24 / 04,3 / 05,11 / 05,2 / 06,6 / 06,12 / 06,17 / 06,1 / 08,8 / 08,1 / 09,3 / 09,10 / 09$ i $5 / 2010$.]

Правилник о плану и програму образовања и васпитања за заједничке предмете у стручним и уметничким школама у Службени гласник СРС - Просветни гласник, бр. 6/90 и у Просветни гласник, бр. 4/91, 7/93, 17/93, 1/94, 2/94, 2/95, 3/95, 8/95, 5/96, 2/2002, 5/2003, 10/2003, 24/2004, 3/2005, 6/2005, 11/2005, 6/2006, 12/2006, 8/2008, 1/2009, 3/2009, 10/2009, 5/2010 и 8/2010 - испр.). [Pravilnik o planu i programu obrazovanja i vaspitanja za zajedničke predmete u stručnim i umetničkim školama u Službeni glasnik SRS - Prosvetni glasnik, br. 6/90 i u Prosvetni glasnik, br. 4/91, 7/93, 17/93, 1/94, 2/94, 2/95, 3/95, 8/95, 5/96, 2/2002, $5 / 2003,10 / 2003,24 / 2004,3 / 2005,6 / 2005,11 / 2005,6 / 2006,12 / 2006$, $8 / 2008,1 / 2009,3 / 2009,10 / 2009,5 / 2010$ i 8/2010 - ispr.).]

Правилник о изменама правилника о плану и програму образовања и васпитања за заједничке предмете у стручним и уметничким школама (број: 110-00-00070/2012-03, од 18. марта 2013. године). [Pravilnik o izmenama pravilnika o planu i programu obrazovanja $i$ vaspitanja za zajedničke predmete u stručnim $i$ umetničkim školama (broj: 110-0000070/2012-03, od 18. marta 2013. godine).] 


\section{Електронски извори}

Vlajković, I. (2010). „Uticaj engleskog jezika na srpski na planu pravopisa, leksike i gramatike u komunikaciji na fejsbuku", u Komunikacija i kultura onlajn 1/1: 183-196. Pristupljeno 22. 2. 2015. www.komunikacijaikultura. org/KK1/KK1Vlajkovic.pdf

Завод за унапређивање образовања и васпитања (2016). „Наставни планови и програми за основне и средње школе”. Приступљено 30. 3. 2016. [Zavod za unapređivanje obrazovanja i vaspitanja (2016). „Nastavni planovi i programi za osnovne i srednje škole”. Pristupljeno 30. 3. 2016.] http://www.zuov.gov.rs/poslovi/nastavni-planovi/nastavni-planovi-os-i-ss/ 
Ivana Đorđev

Kindergarten Teachers' College „Mihailo Palov“

ivanacurcin@yahoo.com

\title{
THE USAGE OF CAPITAL LETTERS IN WRITTEN PAPERS OF HIGH SCHOOL STUDENTS
}

\begin{abstract}
Summary
In this paper we present an extract from a larger research on high school student's adherence to the orthography norms in their written papers. The usage of capital letters will be explored in 3.135 written papers from six schools, which differ in profile and territorially, by determining: the total number and the density (percentually) of mistakes in the usage of capital letters in the written papers; the average density and number of orthography mistakes in the usage of capital letters in high school students' written papers in relation to the students' age, school in which they are enrolled, as well as the grades which they achieve in written papers. Research results show that high school students make in average 0.3 mistakes in the usage of capital letters in one written paper. The most common mistake is using capital letters where they must not be used. Mistakes in the usage of capital letters are most common in the most successful written papers, and the highest density of mistakes in the usage of capital letters was in the papers of students from the specialized grammar school. Mistakes in the usage of capital letters are a consequence of the influence of foreign languages on Serbian, the habits which they have gained during electronic communication, the neglection of orthography classes from the first years of high school, the lack of a connection between orthography and literature classes, but also the students' lack of ability to apply the orthography rules in the varied examples in their written papers. It is considered that additional effort should be made in the teaching practice so that the functional literacy of our students could be improved. In the preparation for written papers, in homework, during practice topics which demand that students use more names of artwork, titles of literary works, place names, historical events etc could be included. In literature classes one should not neglect to teach the correct writing of complex names of characters in literary works, names of writers, writing of the epoche names. It is presumed that the tasks should defer regarding students' age, but also the success level which they achieve in the written papers.
\end{abstract}

Key words: high school, orthography, orthography mistakes, Serbian language, teaching practice, usage of capital letters, written papers.

Примљено: 31. 3. 2016.

Прихваћено: 5. 5. 2016. 